\title{
The status of weed biological control in Vanuatu
}

\author{
Michael D. Day', Sylverio Bule² \\ I Biosecurity Queensland, Department of Agriculture and Fisheries, GPO Box 267, Brisbane, Qld 4001, \\ AUSTRALIA 2 Biosecurity Vanuatu, PMB 9086, Port Vila, VANUATU \\ Corresponding author: Michael D. Day (michael.day@daf.qld.gov.au)
}

Academic editor: C. Daehler | Received 2 November 2015 | Accepted 4 March 2016 | Published 23 June 2016

Citation: Day MD, Bule S (2016) The status of weed biological control in Vanuatu. In: Daehler CC, van Kleunen M, Pyšek P, Richardson DM (Eds) Proceedings of $13^{\text {th }}$ International EMAPi conference, Waikoloa, Hawaii. NeoBiota 30 : 151-166. doi: 10.3897/neobiota.30.7049

\begin{abstract}
Biological control of weeds in Vanuatu began in 1935, with the introduction of the tingid Teleonemia scrupulosa to control Lantana camara. To date, nine biological control agents have been intentionally introduced to control eight weed species. Seven of these agents have established on their respective hosts while an eighth, Zygogramma bicolorata, an agent for Parthenium hysterophorus has only recently been released and establishment is unlikely. The fate of a ninth agent, Heteropsylla spinulosa, released for the control of Mimosa diplotricha is unclear. Six other biological control agents, including Epiblema strenuana which was first detected in 2014 on P. hysterophorus on Efate have spread into the country unintentionally. Control of the target weeds range from inadequate to very good. By far the most successful agent has been Calligrapha pantherina which was introduced to control Sida acuta and Sida rhombifolia. The beetle was released on 14 islands and managed to spread to at least another 10 islands where it has effectively controlled both Sida spp. Control of the two water weeds, Eichhornia crassipes by Neochetina bruchi and N. eichhorniae and Pistia stratiotes by Neohydronomus affinis, has also been fairly good in most areas. Two agents, T. scrupulosa and Uroplata girardi, were released on L. camara, and four other agents have been found on the weed, but L. camara is still not under adequate control. The rust Puccinia spegazzinii was first released on Mikania micrantha in 2012 and successfully established. Anecdotal evidence suggests that it is having an impact on $M$. micrantha, but detailed monitoring is required to determine its overall impact. Future prospects for weed biological control in Vanuatu are positive, with the expected greater spread of recently released agents and the introduction of new agents for P. hysterophorus, L. camara, Dolichandra unguis-cati and Spathodea campanulata.
\end{abstract}

\section{Keywords}

biological control, Eichhornia crassipes, Pistia stratiotes, Mikania micrantha, Sida acuta 


\section{Introduction}

For many farmers in Vanuatu and the South Pacific in general, weeds are a major problem, outcompeting or smothering food crops, and decreasing food security and income. Conventional control of weeds is not always feasible, as herbicides are expensive and beyond the means of most subsistence farmers, while manual control through slashing or hand-pulling is labour intensive (Orapa 2001, Day et al. 2012). Both means of control require constant follow-up, as not all plants are killed or plants can regrow from fragments left behind following slashing. Chemicals can also affect other plant species, contaminate water supplies and have human health issues, as safety equipment is not always available to farmers (Orapa 2001, Day et al. 2012). Thus, biological control is often seen as the only safe, feasible long-term management option for many exotic weed species in Vanuatu.

Biological control of weeds was first undertaken in Vanuatu in 1935, with the introduction of the tingid, Teleonemia scrupulosa Stål (Hemiptera: Tingidae) to control Lantana camara L. sens. lat. (Verbenaceae). Teleonemia scrupulosa had been originally introduced into Hawaii in 1902 (Swezey 1923), before being released into Fiji and then from there into Vanuatu (Winston et al. 2014).

A total of nine biological control agents have been introduced into Vanuatu to control eight of the major exotic weed species present (Winston et al. 2014). In addition to L. camara, these species are the pasture weeds, Sida acuta Burm. f., S. rhombifolia L. (Malvaceae), Mimosa diplotricha C. Wright (Fabaceae) and Parthenium hysterophorus L. (Asteraceae), a fast growing vine Mikania micrantha Kunth (Asteraceae), which can quickly smother other vegetation, and two aquatic weeds, Eichhornia crassipes (Mart.) Solms (Pontederiaceae) and Pistia stratiotes L. (Araceae) (Winston et al. 2014). All of these weed species are native to tropical America and had been introduced either intentionally as ornamentals or accidentally into Vanuatu through contamination of imported goods.

The nine biological control agents were deliberately introduced and had been thoroughly tested and released elsewhere prior to their introduction into Vanuatu to ensure the introduced species are host specific and would not be a risk to crops or native species. In addition to the nine deliberate introductions, five other known biological control agents have found their way unintentionally into Vanuatu (Winston et al. 2014), possibly on imported plants or on machinery.

This paper reports on the biological control agents introduced into Vanuatu and provides an update on their distribution within Vanuatu and their status in controlling their respective target weed species.

\section{Materials and methods}

The nine intentionally introduced biological control agents were first imported into the quarantine facility at the office of Biosecurity Vanuatu in Port Vila. There, the agents were reared through one generation by Biosecurity Vanuatu staff before being mass- 
reared and field-released on their target weed. For the aquatic weeds, E. crassipes and $P$. stratiotes, insects were reared on their respective target weed in above-ground swimming pools similar to those outlined by Julien et al. (1999). Insect biological control agents for the terrestrial weeds were reared on potted plants of their respective hosts in organzamesh screened, aluminium-framed cages $(90 \times 45 \times 45$ high $\mathrm{cm})$, using methods similar to those used by the research organisation from which the particular biological control agent was imported. The rust Puccinia spegazzinii De Toni (Pucciniales: Pucciniaceae), an agent introduced to control $M$. micrantha, was cultured in a similar way to that outlined in Day et al. (2013b). Rearing and culturing methods were adapted to local conditions but maintained the general essence of maintaining an adequate supply of healthy pest-free plants, keeping insect generations separate and maintaining good records.

The distribution of weeds that are or have been targeted for biological control in Vanuatu was recorded in a database which documents the date each weed was first recorded in a particular location, as well as location data, including a GPS waypoint and features of the infestation such as its size and the land type infested. The database was compiled following weed surveys conducted by staff from Biosecurity Vanuatu and the Ministry of Agriculture over 2000-2015 during which biological control agents were released. The presence of agents, such as T. scrupulosa or Uroplata girardi Pic (Coleoptera: Chrysomelidae), which were released prior to the establishment of the database, was also recorded for each site.

All biological control agents were released on their target weed in as many places as possible by Biosecurity Vanuatu staff, using similar techniques and numbers used by other organisations experienced with the agents. Records of all field introduced were documented for each biological control agent. For the agents that were released prior to the establishment of the database, releases were only recorded for new releases at sites where the agents were not already present during the field surveys. Release sites were later monitored to determine establishment of each agent and other known sites of the weeds were checked to determine if the agents had naturally spread to these sites. For all weeds and in particular the aquatic weeds, photos were taken before and at intervals after the release of biological control agents to help document the impact of the agents.

More detailed monitoring of some of the biological control agents on weeds on Efate was conducted by Biosecurity Vanuatu staff. This included the monitoring of $\mathrm{Ne}$ ochetina eichhorniae Warner (Coleoptera: Erirhinidae) on E. crassipes and Calligrapha pantherina Stål (Coleoptera: Chrysomelidae) on S. acuta. More recently, monitoring of P. spegazzinii on M. micrantha and the moth Epiblema strenuana (Walker) (Lepidoptera: Tortricidae) on $P$. hysterophorus, is documenting the impact of these recently introduced biological control agents on their respective targets. At each site, plant parameters such as plants per unit area and height were measured, while the number individual insects, feeding scars, galls or pustules were recorded, depending on the biological control agent.

To capture the benefits of releasing $C$. pantherina, a socio-economic study was conducted eight years after the first release of the insect, to determine whether there was more or less $S$. acuta after $C$. pantherina was released, as well as the level of change in weed density, control effort, crop or beef production and income. 
By constantly updating where biological control agents had established and to where they had spread naturally, sites where the agents were absent could be targeted for future releases, paying particular attention to climatic and habitat requirements of each agent. This ensured a more efficient use of biological control agents and that they were not released in areas where they were already present. This is particularly important as the numbers of biological control agents reared is limited and there are a large number of islands where field releases need to be conducted.

Changes in plants $/ \mathrm{m}^{2}$ and stem height of weeds following releases were assessed using t tests using Genstat (Version 16 2014).

\section{Results}

To date, seven of the nine biological control agents deliberately released in Vanuatu have established (Table 1). One agent, Zygogramma bicolorata Pallister (Coleoptera: Chrysomelidae), recently introduced to control P. hysterophorus, failed to establish. The establishment of a ninth agent, the psyllid Heteropsylla spinulosa Muddiman, Hodkinson \& Hollis (Hemiptera: Psyllidae), for the control of $M$. diplotricha, is unconfirmed.

A further six biological control agents, which have been introduced in other countries, have been found in Vanuatu, presumably being introduced unintentionally on cargo or by natural spread from elsewhere in the Pacific. Four of these agents were found on L. camara and one each on P. hysterophorus and Elephantopus mollis Kunth (Asteraceae) (Table 2).

Over 720 sites, covering 30 islands, including all major islands have been surveyed over the last 15 years (Fig. 1a). However, many of the smaller or remote islands were not covered, due to the difficulty in accessing them.

Overall, control of the target species by all biological control agents, including the unintentionally introduced agents, ranges from inadequate to very good. By far the most successful agent is the leaf-feeding beetle $C$. pantherina for the control of S. acuta and S. rhombifolia. The beetle was introduced into Vanuatu in 2005 from Fiji, following its introduction first into Australia in 1989 (Winston et al. 2014). It was deliberately released at 45 sites on 14 islands and established at 41 sites on 11 islands. Field releases on three islands in the Torres Group were conducted only recently, in August 2015, so it is too early to determine if the beetle has established at those sites.

Calligrapha pantherina subsequently spread from sites where it established to a further 365 sites, covering 21 islands, with complete control of S. acuta being reported at almost all sites where the beetle is present (Fig. 1b).

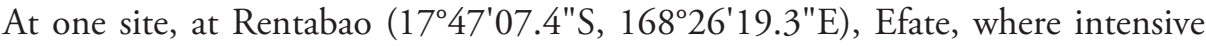
monitoring was conducted, the beetle significantly reduced the populations of $S$. acuta from 29 plants $/ \mathrm{m}^{2}$ in March 2005, just after the beetle was released to less than 4 plants $/ \mathrm{m}^{2}$ seven months later $(\mathrm{t}=4.08 ; \mathrm{p}<0.001)$ (Fig. 2).

A socio-economic study conducted eight years after the release of $C$. pantherina, found that the percentage of farmers who had to control S. acuta decreased from $96 \%$ 
Table I. A list of the target weed species and all biocontrol agents that have been deliberately introduced into Vanuatu, along with the year of introduction, their status and the degree of impact on the target weed.

\begin{tabular}{|c|c|c|c|c|}
\hline Weed & Biocontrol agent & $\begin{array}{l}\text { Year of } \\
\text { release }\end{array}$ & Established? & Impact \\
\hline \multicolumn{5}{|l|}{ Araceae } \\
\hline \multirow[t]{2}{*}{ Pistia stratiotes $\mathrm{L}$. } & Coleoptera: Curculionidae & & & \\
\hline & Neohydronomus affinis Hustache & 2006 & Yes & Variable \\
\hline \multicolumn{5}{|l|}{ Asteraceae } \\
\hline \multirow[t]{2}{*}{ Mikania micrantha Kunth } & Pucciniales: Pucciniaceae & & & \\
\hline & Puccinia spegazzinii De Toni & 2012 & Yes & $\begin{array}{c}\text { Still } \\
\text { validating }\end{array}$ \\
\hline \multirow[t]{2}{*}{ Parthenium hysterophorus $\mathrm{L}$. } & Coleoptera: Chrysomelidae & & & \\
\hline & Zygogramma bicolorata Pallister & 2014 & No & None \\
\hline \multicolumn{5}{|l|}{ Fabaceae } \\
\hline \multirow[t]{2}{*}{ Mimosa diplotricha C. Wright } & Hemiptera: Psyllidae & & & \\
\hline & $\begin{array}{l}\text { Heteropsylla spinulosa Muddiman, } \\
\text { Hodkinson \& Hollis }\end{array}$ & 1994 & Unknown & Unknown \\
\hline \multicolumn{5}{|l|}{ Malvaceae } \\
\hline \multirow[t]{2}{*}{ Sida acuta Burm. f. } & Coleoptera: Chrysomelidae & & & \\
\hline & Calligrapha pantherina Stål & 2005 & Yes & High \\
\hline \multirow[t]{2}{*}{ Sida rhombifolia $\mathrm{L}$. } & Coleoptera: Chrysomelidae & & & \\
\hline & Calligrapha pantherina Stål & 2005 & Yes & High \\
\hline \multicolumn{5}{|l|}{ Pontederiaceae } \\
\hline \multirow[t]{3}{*}{ Eichhornia crassipes (Mart.) Solms } & Coleoptera: Erirhinidae & & & \\
\hline & Neochetina bruchi Hustache & 2013 & Yes & $\begin{array}{c}\text { Still } \\
\text { validating }\end{array}$ \\
\hline & Neochetina eichhorniae Warner & 2004 & Yes & High \\
\hline \multicolumn{5}{|l|}{ Verbenaceae } \\
\hline \multirow[t]{4}{*}{ Lantana camara L. sens. lat. } & Hemiptera: Tingidae & & & \\
\hline & Teleonemia scrupulosa Stål & 1935 & Yes & Slight \\
\hline & Coleoptera: Chrysomelidae & & & \\
\hline & Uroplata girardi Pic & 1983 & Yes & Slight \\
\hline
\end{tabular}

before $C$. pantherina was released to $14 \%$ after the beetle was released and controlled the weed. Furthermore, $78 \%$ of farmers thought their production had increased by over $50 \%$ since the release of the beetle (Fig. 3).

Calligrapha pantherina will also attack S. rhombifolia, although to a lesser extent than S. acuta. Sida rhombifolia is widespread throughout Vanuatu but it is not found in the same densities as $S$. acuta. It is expected that $S$. rhombifolia will be kept at such low densities by $C$. pantherina that it will not be considered a problem.

The biological control of P. stratiotes by Neohydronomus affinis Hustache (Coleoptera: Curculionidae) was also highly successful. The beetle was introduced into Vanuatu in 2006 from Papua New Guinea, following its introduction first into Australia in 1982. It was deliberately released at 14 sites on six islands and establishment has been confirmed on five islands. On a sixth island, releases were only conducted in 
Table 2. A list of the target weed species and all known biocontrol agents that were not deliberately introduced into Vanuatu but have been found in the country.

\begin{tabular}{ccccc}
\hline Weed & Biocontrol agent & $\begin{array}{c}\text { Year first } \\
\text { reported }\end{array}$ & Established? & Impact \\
\hline $\begin{array}{c}\text { Asteraceae } \\
\text { Elephantopus mollis Kunth }\end{array}$ & $\begin{array}{c}\text { Diptera: Tephritidae } \\
\text { Petraenaresta obscuriventris (Loew) } \\
\text { Lepidoptera: Tortricidae } \\
\text { Epiblema strenuana (Walker) }\end{array}$ & 1984 & Yes & Unknown \\
Verbenaceae & $\begin{array}{c}\text { Diptera: Agromyzidae } \\
\text { Lantana camara L. sens. lat. }\end{array}$ & Yes & Still validating \\
& $\begin{array}{c}\text { Calycomyza lantanae (Frick) } \\
\text { Lepidoptera: Tortricidae } \\
\text { Crocidosema lantana } \text { Busck } \\
\text { Lepidoptera: Erebidae }\end{array}$ & 2012 & Yes & Slight \\
& $\begin{array}{c}\text { Hypena laceratalis Walker } \\
\text { Diptera: Agromyzidae } \\
\text { Ophiomyia lantanae } \text { (Froggatt) }\end{array}$ & 2012 & Yes & Slight \\
& 2012 & Yes & Slight \\
\hline
\end{tabular}

November 2014 and the site has yet to be checked for establishment. The beetle has spread naturally to another 20 sites on three of the islands (Fig. 1c).

Control of $P$. stratiotes was generally very good in open, sunny areas. At one site at Belmol (153 $\left.35^{\prime} 02.1^{\prime \prime S}, 167^{\circ} 06^{\prime} 07.3^{\prime \prime E}\right)$ on Espiritu Santo, control was achieved three years after $N$. affinis was released (Fig. 4). However, control has not been achieved where $P$. stratiotes is growing in ponds and creeks sheltered by large trees. In fact, in a small pond shaded by trees, $500 \mathrm{~m}$ from the lake at Belmol where control was achieved, $P$. stratiotes completely covers the water surface and little beetle activity has been observed.

At other sites e.g. Tagabe River (17\%42'27.8"S, 168 $\left.19^{\circ} 09.7^{\prime \prime E}\right)$, Port Vila and Mele Stream (17 $\left.41^{\prime} 14.0^{\prime \prime S}, 168^{\circ} 16^{\prime} 04.2^{\prime \prime E}\right)$ (both on Efate), P. stratiotes infestations fluctuate. Plants heavily damaged by $N$. affinis can be flushed out during heavy rains, but infestations can reappear, having developed from small plants remaining or from seeds in the soil. In these situations, $N$. affinis may need to be re-released. Neohydronomus affinis also needs to be released on four islands where recent surveys found new infestations of the weed (Fig. 1c). An additional 15 sites containing only small infestations of $P$. stratiotes were observed and local landholders were advised to remove the plants by hand.

Two biological control agents, N. eichhorniae (2004) and N. bruchi Hustache (2013) were introduced into Vanuatu for the control of E. crassipes, following numerous reports that control is more effective if both beetle species are utilised (e.g. Julien et al. 1999). Together, the beetles have been released on nearly half of the 25 sites on six islands where E. crassipes has been reported. At least one of the beetles has established at six sites covering three islands (Fig. 1d). Complete control of E. crassipes has occurred at only three sites to date. However, with the recent introduction of $N$. bruchi, the number of sites controlled is expected to increase. At eight other sites, landholders have been advised to remove the weed by hand, as populations are small and confined. 

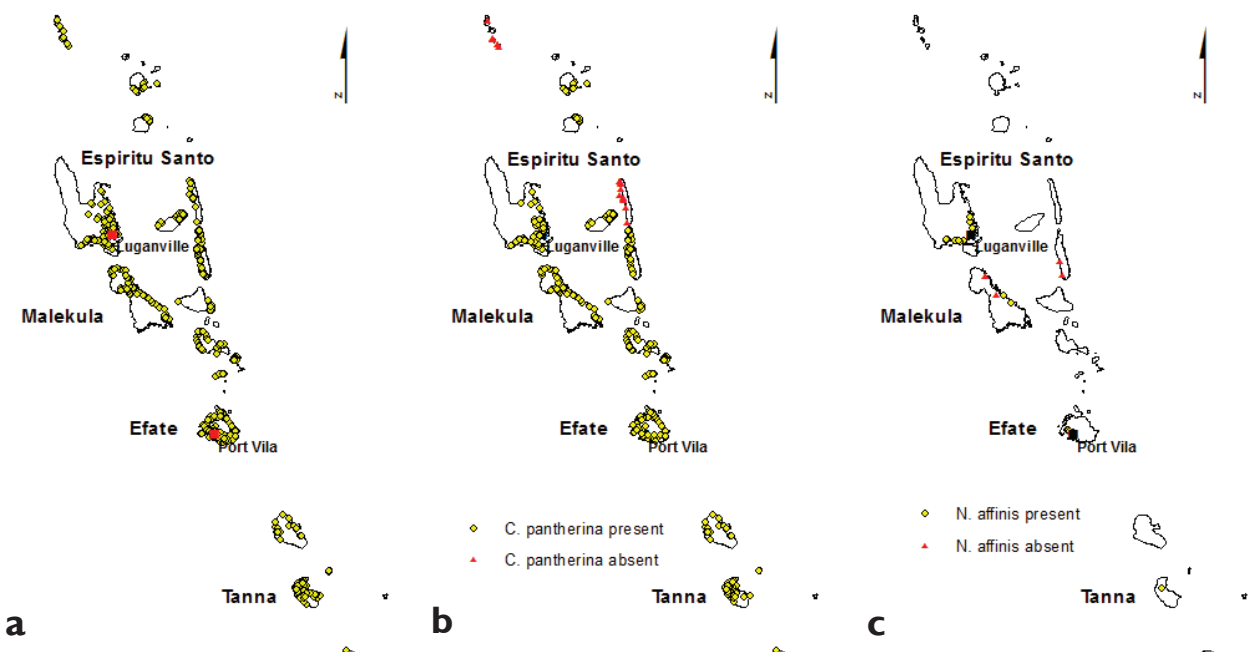<smiles>C[Al]C=[Zr]</smiles>

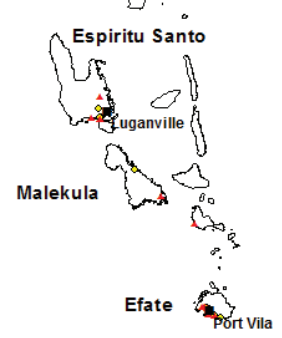

Neochetina spp. absent

- Neochetina spp. present

d

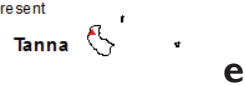

0

e

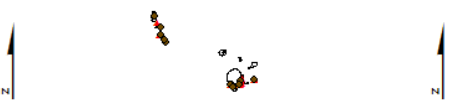

.

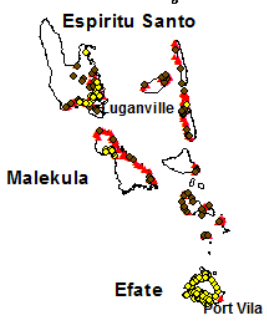

- P. spegazzinii present

- P. spegazzinii released

- P. spegazzinii not released

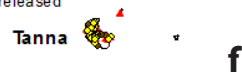

2

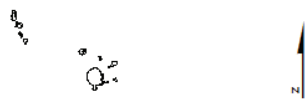

0 .
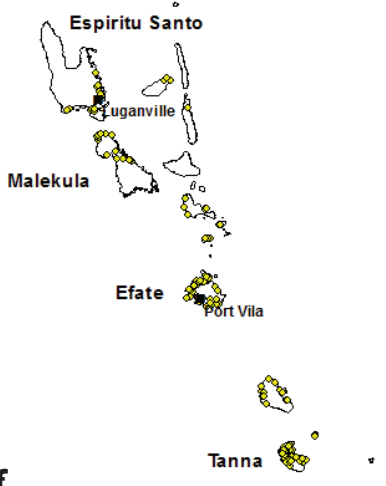

(b)

Figure I. Maps showing all sites in Vanuatu where surveys for weeds have been conducted over the past 15 years (a), the distribution of Sida acuta and where Calligrapha pantherina has established and is absent (b), the distribution of Pistia stratiotes in Vanuatu and where Neohydronomus affinis has established and is absent (includes sites where eradication has been advised) (c), the distribution of Eichhornia crassipes in Vanuatu and where Neochetina spp. have established and are absent (includes sites where eradication has been advised) (d), the distribution of Mikania micrantha in Vanuatu and where Puccinia spegazzinii has established, been released but establishment not confirmed and where no releases have been conducted (e), and the distribution of L. camara in Vanuatu (f).

For several sites e.g. Mele Stream, E. crassipes populations, as with P. stratiotes, fluctuated dramatically, as infestations get flushed out during heavy rain, only to reappear from any small plants remaining or from seeds in the soil. In other situations, E. crassipes occurs in ephemeral ponds (e.g. at Belmol) which dry out occasionally. 


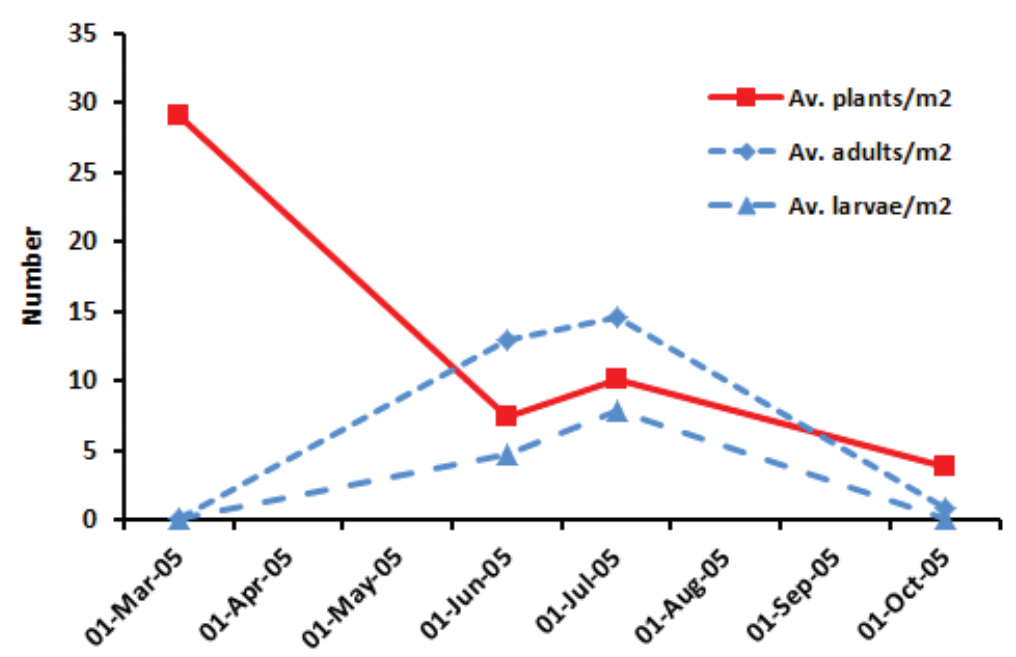

Figure 2. The effect of Calligrapha pantherina on the numbers of plants $/ \mathrm{m}^{2}$ of Sida acuta at Rentabao, Efate.

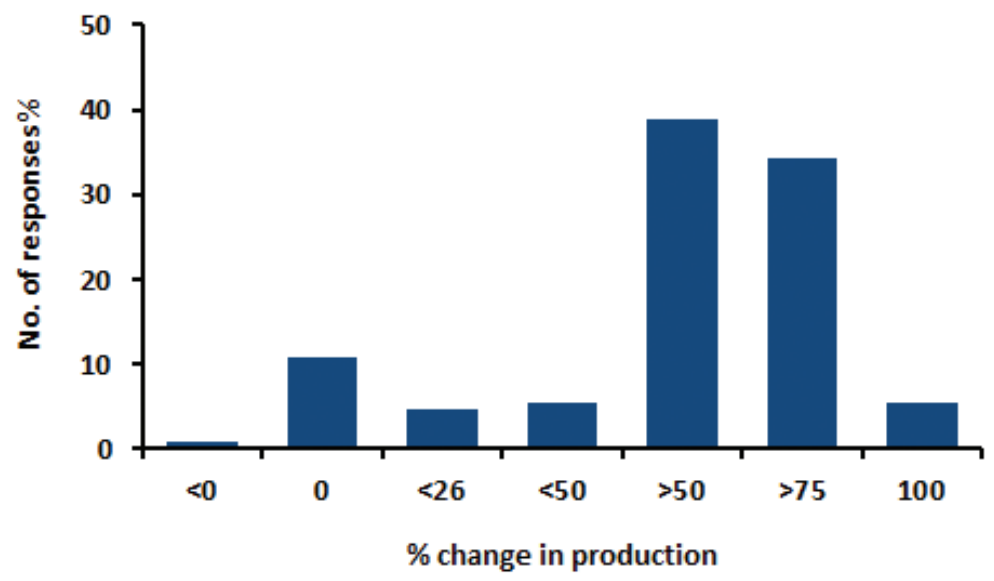

Figure 3. The percentage of respondents in Vanuatu who observed categories of percent change in production following the release of Calligrapha pantherina on Sida acuta.

Any beetles which are present either disperse away from the ponds or die. When the ponds refill after rain, the infestation returns from seeds germinating from the soil. However, in both situations, the insects may no longer be present and may have to be re-introduced.

At Teouma River $\left(17^{\circ} 47^{\prime} 22.1^{\prime \prime S}, 168^{\circ} 23^{\prime} 02.7^{\prime \prime E}\right)$, Efate, there was a significant reduction in the average length of the second petiole within 12 months, following the release of $N$. eichhorniae in November $2004(93.3 \pm 4.9 \mathrm{~cm}$ versus $37.7 \pm 2.2 \mathrm{~cm})(\mathrm{t}=$ 

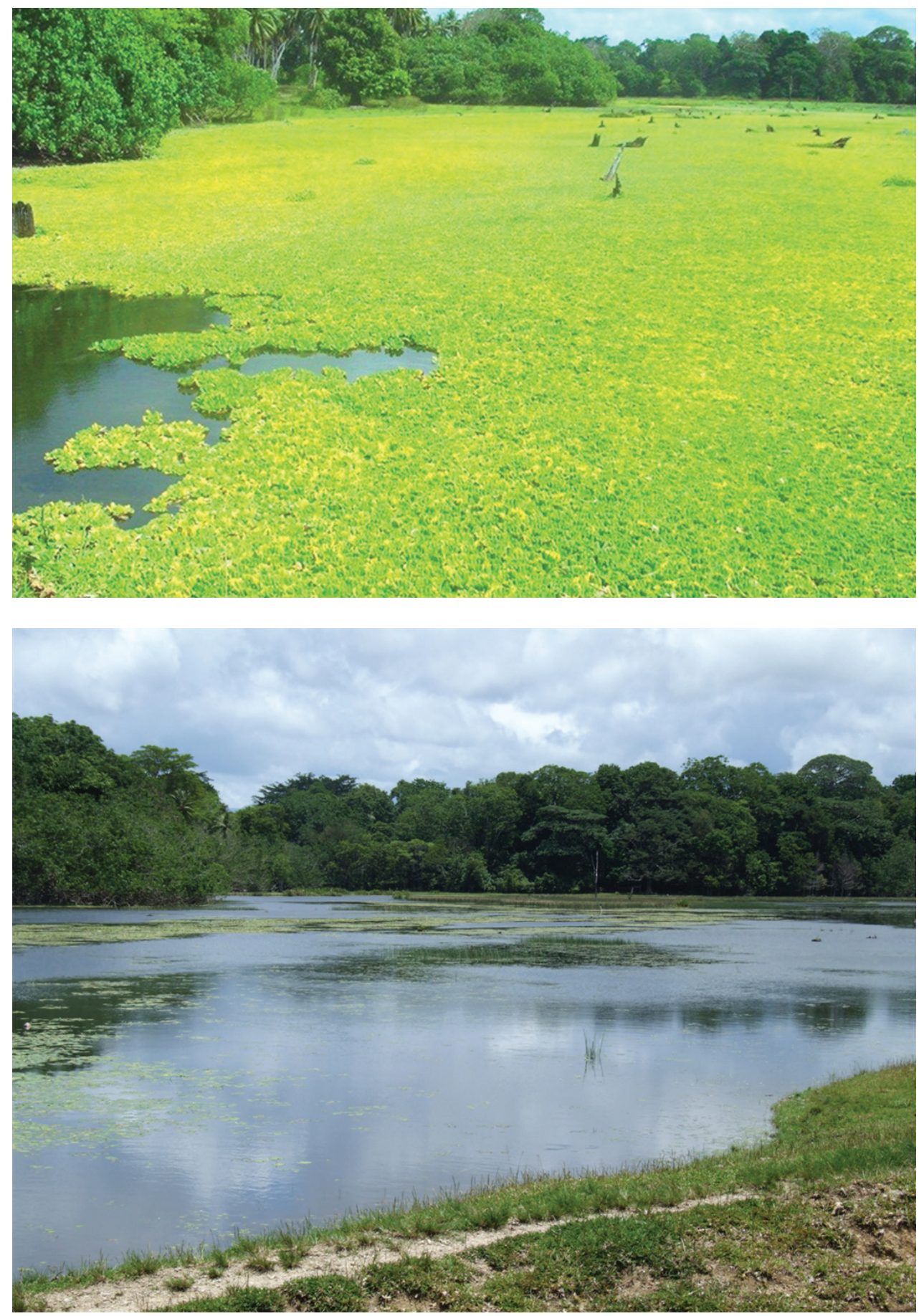

Figure 4. Belmol Pond, Espiritu Santo in 2005 before (top) and in 2008 after (bottom) Neohydronomus affinis was released to control Pistia stratiotes. 

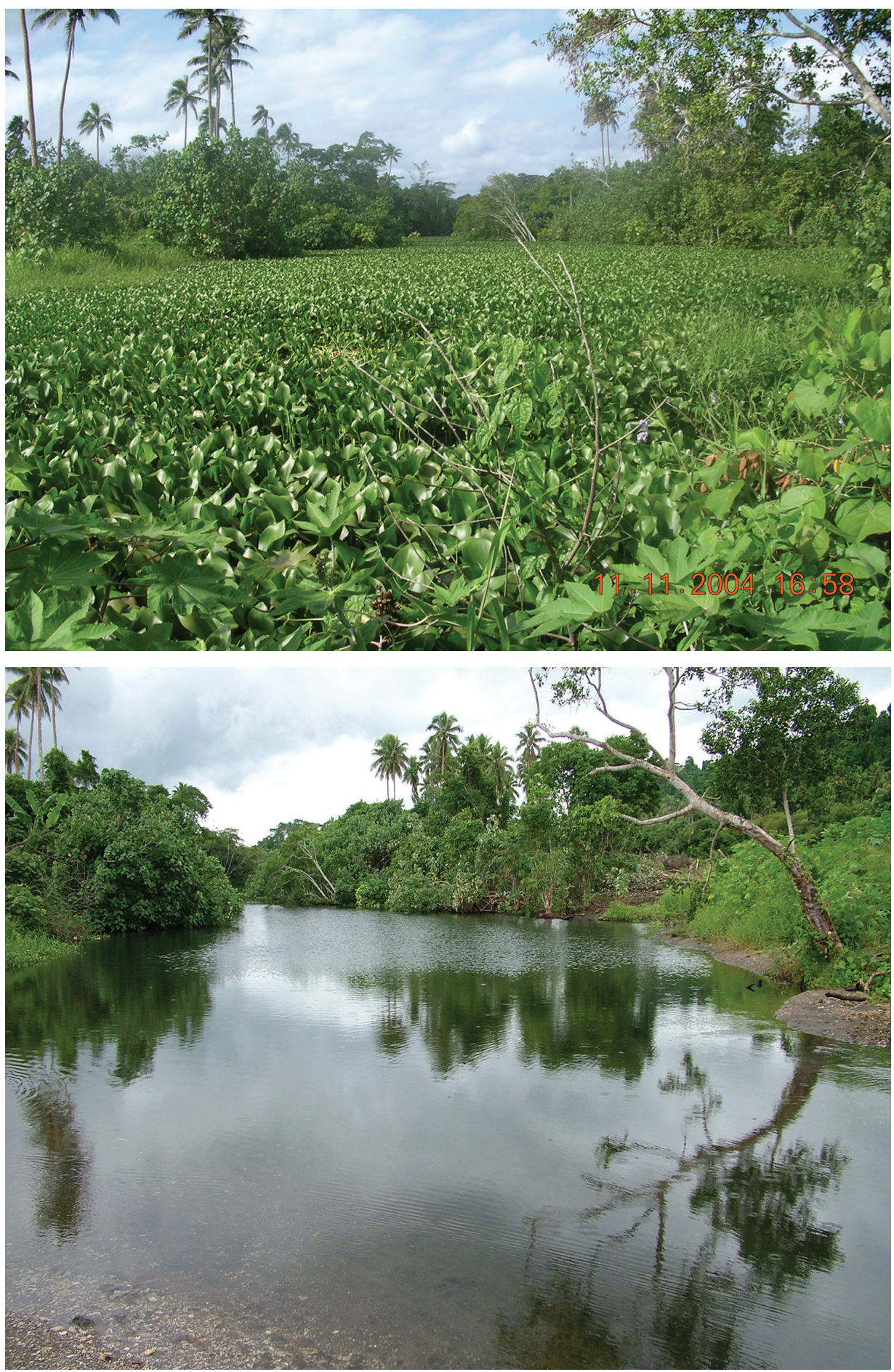

Figure 5. Teouma River, Efate in 2004 before (top) and in 2008 after (bottom) Neochetina eichhorniae was released to control E. crassipes. 
10.68; $\mathrm{p}<0.001)$. The overall percentage cover by E. crassipes decreased from $100 \%$ in November 2004 to $<5 \%$ in 2008, following the release of $N$. eichhorniae (Fig. 5).

In 2012, the rust P. spegazzinii was introduced to Vanuatu from Papua New Guinea where it had been found to be highly damaging to $M$. micrantha (Day et al. 2013c). The rust was released widely in Vanuatu, at over 150 sites, covering 25 islands and establishment has been confirmed so far at over 50 sites on seven islands, including the main islands of Efate, Malekula, Espiritu Santo and Tanna. Puccinia spegazzinii has also spread up to $20 \mathrm{~km}$ to over 100 sites, covering five islands (Fig. 1e). The remaining 18 islands still need to be checked for establishment. Detailed field monitoring has been initiated on Efate but it is too early to evaluate the impact of the rust. However, anecdotal observations have suggested that some populations of $M$. micrantha, especially those in higher altitude areas on Efate, have decreased following the establishment of P. spegazzinii.

Biological control of L. camara in Vanuatu has been inadequate, despite six agents being found. Lantana camara has been found on 18 islands and at least one agent is present on 15 of these islands (Fig. 1f). On many islands, L. camara is not considered a major weed, as it is found in only small clumps, often along roadsides and fence lines. However, on Tanna and Espiritu Santo, there are some very large infestations. Two agents, T. scrupulosa (1935) and U. girardi (1983), were deliberately introduced, with the latter being the most common and widespread, being found on 15 islands. The remaining four species, Ophiomyia lantanae (Frogatt) (Diptera: Agromyzidae) (first reported in Vanuatu in 1983), Calycomyza lantanae (Frick) (Diptera: Agromyzidae), Crocidosema lantana Busck (Lepidoptera: Tortricidae) and Hypena laceratalis Walker (Lepidoptera: Erebidae), all first found in 2012, were either introduced unintentionally or spread naturally from elsewhere in the Pacific. These are less common and it's possible that they may have been missed in earlier surveys. Together, they have little impact on L. camara and additional agents are required to control the large infestations on Tanna and Espiritu Santo.

The leaf-feeding beetle, Z. bicolorata was imported into Vanuatu in early 2014 to control $P$. hysterophorus, when infestations became too numerous and widespread to effectively eradicate the species. The beetle was obtained from Queensland, Australia, where it is aiding control of P. hysterophorus in central Queensland (Dhileepan and McFadyen 2012). The beetle was released at two sites on Efate and one site on Tanna. However, cyclone Pam, which hit Vanuatu in March 2015, destroyed the three sites, as well as the rearing facilities at Port Vila and the rearing colony was lost. The beetle will be re-introduced in early 2016 .

In late 2014 , the stem-boring moth E. strenuana was found attacking $P$. hysterophorus at several sites near Port Vila. It is not known how the moth arrived in Vanuatu, but it is suspected that it may have come in on imported machinery from Queensland, much the same way as $P$. hysterophorus came into the country. Field monitoring has been established at one particularly large infestation near Port Vila to document the impact of the agent on $P$. hysterophorus. 
The psyllid, H. spinulosa was introduced into Vanuatu in 1994 for the control of M. diplotricha. Surveys from 2012 to 2015, recorded many sites covering four islands with damage similar to that caused by the psyllid but no adults have ever been found. In some areas on the island of Malekula, which receive high rainfall, it is possible that adults are washed off regularly and so are not always visible. However, on other islands such as Efate, Espiritu Santo or Tanna, rainfall is not so great and adults have still not been observed. Despite the damage to $M$. diplotricha, the plant is not under control and consideration will be given to re-importing the psyllid if additional planned surveys fail to confirm its presence.

Another biological control agent, Tetraeuaresta obscuriventris (Loew) (Diptera: Tephritidae) naturally spread into Vanuatu with its target weed, Elephantopus mollis, but neither have been found during weed surveys.

Two other weeds, which are planned for biological control, are being recorded more widely over time. Dolichandra unguis-cati (L.) L. G. Lohmann (Bignoniaceae) was originally thought to occur at only one site, on Efate but it has now been found at seven sites, covering three islands and it is feared that birds will spread it further with time. Spathodea campanulata P. Beauv. (Bignoniaceae) is present on eight islands but recording infestations of this weed began in only 2013. Infestations of $S$. campanulata on islands surveyed prior to this date, would not have been recorded, as the species was not on the list to document.

\section{Discussion}

Nine biological control agents have been deliberately released against eight target weeds in Vanuatu, with the establishment of seven agents being confirmed. A further six biological control agents have found their way into Vanuatu, either through natural means or introduced unintentionally. Overall, these agents are controlling some of the most important exotic weeds in Vanuatu, resulting in little or no active control by land managers. The flow-on effects of successful biological control of these species include better access to water, reduced costs of managing weeds and increased production, resulting in increased income and food security (Dovey et al. 2004; Day et al. 2013a).

All of the biological control agents deliberately released in Vanuatu had been previously tested and released in other countries, and were considered to be highly damaging to their respective host plant in at least one other country (Winston et al. 2014). There are several significant benefits in targeting biological control agents that have a proven record of specificity and controlling the target weed. First, the utilization of host specific agents is highly efficient (Dodd and Hayes 2009, Paynter et al. 2015), as the testing of a single potential biological agent may cost upwards of US\$200,000, which could be prohibitive for many countries. Second, in many countries, the infrastructure in the form of a secure quarantine and glasshouses, as well as technical expertise may be lacking to import biological control agents and to conduct their own host specificity testing prior to an agent's release (Dovey et al. 2004). 
Third, the probability of the agent being effective in a new country is greater if it has been successful in other countries, especially those with similar climatic ranges (Julien et al. 2007). This makes the use of proven biological control agents extremely cost-effective, with very little risk to non-target species (Dovey et al. 2004; Julien et al. 2007; Paynter et al. 2015). Numerous biological control agents have been released in the Pacific following detailed host specificity testing in Australia or elsewhere. In addition, once an agent has been released in one country in the Pacific, it has often been released in other countries e.g. C. pantherina was first introduced into Fiji from Australia, prior to then being introduced into Vanuatu. Teleonemia scrupulosa was introduced into Hawaii then Fiji and then to several other countries in the Pacific, including Vanuatu (Winston et al. 2014).

A final benefit in utilizing proven biological control agents is that it allows researchers, especially those in countries with little experience in biological control, to develop basic skills and techniques in rearing and field release of agents, prior to tackling new targets where little work has been already conducted.

Many biological control projects in the Pacific are donor-funded and there is a tendency to invest in projects with a high chance of success i.e. utilizing tried and proven agents rather than investing in novel projects where the chance of success is not guaranteed (Paynter et al. 2015). Consequently, countries may end up targeting weed species, which are not the most important weeds in the country. This is because the most important weeds in a country may not be targets for biological control anywhere else or there are no effective agents and so attract a much higher cost to research due to the additional steps of exploration and host specificity testing of potential agents (Julien et al. 2007). Thus, there is a higher level of uncertainty, as good agents may not be found or may not be host specific, than with targeting weeds which have readily available and effective biological control agents (Julien et al. 2007; Dodd and Hayes 2009).

Following a series of regional workshops, $M$. micrantha was only rated as the second most important weed in the Pacific, after Merremia peltata (L.) Merr. (Convolvulaceae) but had better prospects for successful biocontrol than $M$. peltata, which is deemed a native plant in some countries. Consequently, a biological control project targeting M. micrantha and involving P. spegazzinii was initiated. Since P. spegazzinii had been previously tested against over 170 plant species, only a relatively few species needed to be tested, thus making its introduction very cost effective and resulting in its release in PNG and Fiji (Day et al. 2013b), prior to its introduction into Vanuatu.

However, even within these donor-funded projects, there are limitations to what can be effectively achieved. This is partly because these projects have a limited life span and secondly, countries such as Vanuatu, Fiji and PNG consist of many islands which may be hard and/or costly to reach. Consequently, it may not be possible to release biological control agents into all areas where the target weeds exist and/or check release sites for establishment in the time frame of a project. Hence, biological control agents still need to be released into many areas, long after projects have been completed. Puccinia spegazzinii has been released on 25 islands in Vanuatu, but establishment has been confirmed on only seven islands, with 18 islands still to be checked. Without 
additional donor funds, the re-distribution or checking of $P$. spegazzinii and other biological control agents is severely hampered.

Despite such limitations, there is no doubt that the introduction of biological control agents into Vanuatu has been of enormous benefit to both weed management in the country and capacity building. The success of biological control in Vanuatu to date creates a strong platform on which to build and develop future projects. Capacity in weed biological control has increased significantly over the years, as well as the linkages with other organisations which conduct biological control.

Researchers in Vanuatu will continue when possible to monitor for agent establishment and release biological control agents into areas where they are not already present. For example, Epiblema strenuana, which is one of the most damaging agents on $P$. hysterophorus in Queensland (Dhileepan and McFadyen 2012), will continue to be redistributed by Biosecurity Vanuatu in the hope that $P$. hysterophorus will be contained, if not controlled, on the only three islands on which the weed has been reported.

Researchers in Vanuatu will also continue to monitor the impact of agents against their target weeds. It is hoped that $P$. spegazzinii will have a similar impact to $M$. micrantha in Vanuatu as it did in PNG, where weed populations were reduced to less than $40 \%$ of their original size (Day et al. 2013c).

As well as the release and monitoring of biological control agents, there is still a need to maintain a campaign of public awareness, so that weeds are controlled before populations become too large and are not spread by people. This particularly applies to the water weeds where plants are often found in drains or maintained in small ponds. While the plants may not be a real problem in these areas, it is still desirable to have them controlled or even eradicated. Birds can move seeds or plants could be moved by people to new ponds or to other islands, thus creating new infestations elsewhere, possibly in areas where the impacts are greater (Parsons and Cuthbertson 1992; Julien et al. 1999).

In addition to on-going projects, consideration has already been given to introducing several more biological control agents for the control of $L$. camara, as well as agents for D. unguis-cati and S. campanulata. For L. camara, possible agents include the budmite, Aceria lantanae Cook (Acari: Eriophyidae), which is showing great promise in reducing flowering and seed set in South Africa and the herring-bone fly Ophiomyia camarae Spencer (Diptera: Agromyzidae), which is widespread both in South Africa and north Queensland and has been responsible for defoliating stands of $L$. camara (Winston et al. 2014).

Three biological control agents for D. unguis-cati have been released in Queensland and two of these, Carvalhotingis visenda Drake \& Hambleton (Hemiptera: Tingidae) and the leaf-feeding beetle Hedwigiella jureceki (Obenberger) (Coleoptera: Buprestidae), show the most promise (Winston et al. 2014). A permit to import C. visenda has been issued by Biosecurity Vanuatu and the insect is likely to be introduced in early 2016 (S. Bule Biosecurity Vanuatu 2015).

Field surveys in the native range of $S$. campanulata in West Africa have found several insects that are showing potential for use as biological control agents. These insects are currently undergoing host specificity testing in South Africa to determine their suitability for introduction into the Pacific (S. Neser pers. comm. 2014). 
The next big challenge for Vanuatu is to secure funding to be able to tackle their most important weeds that have not yet been the target of biological control elsewhere. These species include Solanum torvum Sw. (Solanaceae) and Senna tora (L.) Roxb. (Fabaceae), which are each found in about 15 Pacific island nations, infesting grazing lands and reducing production. Extensive exploration on both species in their native ranges to locate potential biological control agents is required, prior to any host specificity being conducted. Due to the increased complexities and costs of such projects, it may be prudent to join with other countries to establish a regional project rather than tackle these weeds alone.

The continual release and re-distribution of current biological control agents in Vanuatu should help control their respective target weeds in areas where the weeds are presently unchecked. The introduction of effective agents for $P$. hysterophorus, $L$. camara, D. unguis-cati and $S$. campanulata should help reduce the impact of these weeds on agriculture and boost food security and income in Vanuatu. The successful implementation and biological control of several weed species in Vanuatu provides an excellent example and opportunity for other countries in the Pacific that also wish to manage similar weed species.

\section{Acknowledgements}

The authors wish to thank the Vanuatu Ministry of Agriculture for assistance in field surveys, the National Agriculture Research Institute, Papua New Guinea for supplying Puccinia spegazzinii, and the Secretariat of the Pacific Community for funding the introduction of Calligrapha pantherina and Neochetina eichhorniae, and for printing posters and public awareness material. Special thanks to the Australian Department of Foreign Affairs and Trade under their Public Sector Linkages Program who funded the recent introduction of three biological control agents and recent surveys throughout Vanuatu. Thanks to Drs A. Pople, T. Johnson, Q. Paynter and C. Daehler who provided comments on earlier drafts of the manuscript.

\section{References}

Day MD, Bofeng I, Nabo I (2013a) Successful biological control of Chromolaena odorata (Asteraceae) by the gall fly Cecidochares connexa (Diptera: Tephritidae) in Papua New Guinea. In: Wu Y, Johnson T, Sing S, Raghu S, Wheeler G, Pratt P, Warner K, Center T, Goolsby J, Reardo R (Eds) Proceedings of the XIII International Symposium on Biological Control of Weeds, Waikoloa (Hawaii USA), September 2011. Forest Health Technology Enterprise Team, Morgantown WV, 400-408.

Day MD, Kawi AP, Ellison CA (2013b) Assessing the potential of the rust fungus Puccinia spegazzinii as a classical biological control agent for the invasive weed Mikania micrantha in Papua New Guinea. Biological Control 67: 253-261. doi: 10.1016/j.biocontrol.2013.08.007 
Day MD, Kawi AP, Fidelis J, Tunabuna A, Orapa W, Swamy B, Ratutini J, Saul-Maora J, Dewhurst CF (2013c) Biology, field release and monitoring of the rust fungus Puccinia spegazzinii (Pucciniales: Pucciniaceae), a biological control agent of Mikania micrantha (Asteraceae) in Papua New Guinea and Fiji. In: Wu Y, Johnson T, Sing S, Raghu S, Wheeler G, Pratt P, Warner K, Center T, Goolsby J, Reardo R (Eds) Proceedings of the XIII International Symposium on Biological Control of Weeds, Waikoloa (Hawaii USA), September 2011. Forest Health Technology Enterprise Team, Morgantown WV, 211-217.

Day MD, Kawi A, Kurika K, Dewhurst CF, Waisale S, Saul-Maora J, Fidelis J, Bokosou J, Moxon J, Orapa W, Senaratne KAD (2012) Mikania micrantha Kunth (Asteraceae) (milea-minute): Its distribution and physical and socioeconomic impacts in Papua New Guinea. Pacific Science 66: 213-223. doi: 10.2984/66.2.8

Day MD, Wiley CJ, Playford J, Zalucki MP (2003) Lantana: Current management status and future prospects. ACIAR, Canberra, $128 \mathrm{pp}$.

Dhileepan K, McFadyen RC (2012) Parthenium hysterophorus L - parthenium. In: Julien M, McFadyen R, Cullen J (Eds) Biological Control of Weeds in Australia. CSIRO Publisher, Melbourne, 448-462.

Dodd S, Hayes L (2009) Report on Pacific Biocontrol Strategy Workshop. Landcare Research Contract Report: LC0910/069. Landcare Research, New Zealand, 1-90.

Dovey L, Orapa W, Randall S (2004) The need to build biological control capacity in the Pacific. In: Cullen JM, Briese DT, Kriticos DJ, Lonsdale WM, Morin L, Scott JK (Eds) Proceedings of the XI International Symposium on Biological Control of Weeds, Canberra (Australia), May 2003. CSIRO Entomology Australia, Canberra, 36-41.

Julien MH, Griffiths MW, Wright AD (1999) Biological control of water hyacinth. The weevils Neochetina bruchi and $N$. eichhomiae: biologies, host ranges, and rearing, releasing and monitoring techniques for biological control of Eichhornia crassipes. ACIAR Monograph No. 60. ACIAR, Canberra, 1-87.

Julien MH, Scott JK, Orapa W, Paynter Q (2007) History, opportunities and challenges for biological control in Australia, New Zealand and the Pacific islands. Crop Protection 26: 255-265. doi: 10.1016/j.cropro.2006.01.019

Parsons WT, Cuthbertson EG (1992) Noxious weeds of Australia. Inkata Press, Melbourne.

Paynter Q, Fowler SV, Hayes L, Hill RL (2015) Factors affecting the cost of weed biocontrol programs in New Zealand. Biological Control 80: 119-127.

Orapa W (2001) Impediments to increasing food security in PNG: the case of exotic weed species. In: Bourke RM, Allen MG, Salisbury JG (Eds) Food security for Papua New Guinea: Proceedings of the Papua New Guinea Food and Nutrition Conference, Lae (Papua New Guinea), June 2000. ACIAR Proceedings No. 99, Canberra, Australia, 308-315.

Swezey OH (1923) Records of introduction of beneficial insects into the Hawaiian Islands. Proceedings of the Hawaiian Entomological Society 5: 299-304.

Winston RL, Schwarzländer M, Hinz HL, Day MD, Cock MJW, Julien MH (2014) Biological Control of Weeds: A World Catalogue of Agents and Their Target Weeds. USDA Forest Service, Forest Health Technology Enterprise Team, Morgantown, West Virginia, FHTET-2014-04: 1-838. 